\title{
Combination of Law-Governing and Virtue-Governing: The Perspective of Social Governance Centering on Zichan
}

\author{
Xiuli Yang \\ Department of Chinese, Shanghai University, Shanghai, China \\ Email: youngerxiuli@163.com
}

How to cite this paper: Yang, X. L. (2017). Combination of Law-Governing and Virtue-Governing: The Perspective of Social Governance Centering on Zichan. Advances in Applied Sociology, 7, 327-340. https://doi.org/10.4236/aasoci.2017.79021

Received: August 8, 2017

Accepted: September 12, 2017

Published: September 15, 2017

Copyright $\odot 2017$ by author and Scientific Research Publishing Inc. This work is licensed under the Creative Commons Attribution International License (CC BY 4.0).

http://creativecommons.org/licenses/by/4.0/

\begin{abstract}
This paper intends to closely examine the abundant historical data on the theory and practice of Zichan's social governance, which were recorded in The Commentary of Zuo. For example: Zichan thought the minister who had good reputation, morality and integrity can make people submit through clemency. Propriety is the law of heaven, the root of earth, and the dependence of people. Zichan cast the penal code, separated the law from traditional rituals, and described severity as fire which is fierce and violent. People feared it, but few died from it. This can be summarized as Law-governing and Virtue-governing. The author used the typical characteristics of social transition in the Spring and Autumn Period, which is a special social transformation from slavery society to feudal society. During that period, the feature of social system is rite disintegration and has a transition from the God to man. It will be argued that based on the social governance which was elaborated by Zichan, and the effects recorded in The Commentary of Zuo, the author considers that the collection and research articles pertaining to this part of the literature can provide materials and ideas of relevance for research on social governance in China, especially the Chinese aristocracy in the Pre-Qin dynasty. The effective forms of governance at that time could enrich the theoretical resources for contemporary China, and may have relevance for scholarly research in political philosophy in other cultures.
\end{abstract}

\section{Keywords}

Zichan, Social Governance, Humanism, Law-Governing, Virtue-Governing, Evaluation 


\section{Introduction}

The writings of the ancient philosophers ${ }^{1}$ are scattered among all kinds of both handed-down and newly-discovered documents. Those philosophers who had monographs have been subject to a thorough research and discussion. The studies on those important figures who have had no monographs handed down concerning their original ideas and actions are few and far between, but these ideas should naturally be evolved into the principal writings on the studied topics, especially those scholars who lived before, and influenced profoundly the different philosophers and authors in the time of the Warring States. The man selected in this paper, named Zichan (子产, ? 522 BCE), affected Confucianism and legalism deeply, responsible for creating China's first meritocracy. But Zichan did not have his own monographs handed down. The theory of social governance which was elaborated by him, and its effects were recorded in The Commentary of Zuo (《左传》), so this should be consulted and studied.

The Commission on Global Governance made a standard definition of global governance in 1995, stating that "Governance is the sum of many ways individuals and institutions, public and private, manage their common affairs. It is a continuing process through which conflicting or diverse interests may be accommodated and co-operative action taken. It includes formal institutions and regimes empowered to enforce compliance, as well as informal arrangements that people and institutions either have agreed to or perceive to be in their interest" (The Commission on Global Governance, 1995). The concept of governance was formed around this time.

But the thought and practice of social governance had existed for a long time. Looking back to the Spring and Autumn period ${ }^{2}$, the patriarchal clan system and feudal system gradually collapsed, associated with the most common social governance disorders during this period. That could be marked by "normative vacuum" and "control failure", both of which not only disturbed and destroyed the original social order, but also served to motivate the birth of new social order. In this era of China's history, these unstable social operations had been in the process of constant transformation, so social governance had become more complex and increasingly important. Zichan who had successfully governed in his state in the late Spring and Autumn period, made an important influence on social governance in this period. Intensive studies on Zichan's thought of social governance could enrich the theoretical resources for contemporary China, and also for Western thought.

\footnotetext{
${ }^{1}$ The ancient philosophers (诸子百家), The different philosophers and authors, referring to the philosophers or their works, and different schools, which outside the Confucianists (such as Lao Zi (老子), Zhuang Zi (庄子), Mo Zi (墨子), etc.) esp. in time of the Warring States (475 221 BCE).

${ }^{2}$ The Spring and Autumn period (春秋时代) was a period in Chinese history from approximately $770 \sim 476$ BCE, which name was derived from the Spring and Autumn Annals, a chronicle of the state of Lu (鲁) $722 \sim 479$ BCE. The social fields concerning politics, economy, military affairs, culture or ideology had stepped into the period of social upheaval, and the most significant development in this period was a major breakthrough in the intellectual sphere, which was called "axis period" of civilization by Jaspers.
} 


\section{Social Governance of Zichan}

\subsection{Zichan's Humanism and Its Characteristics}

Zichan's emphas on humanism, as the logical development of the humanistic idea in the Spring and Autumn Period, leads to the research on the reconstruction of the social system. The original social governance function in religious doctrine style had been lost, as well as the understanding of fate in this period, which had been encapsulated in the sacred religion, namely the gods ruling the nation's fate, with the king of Zhou (周王) being the mere figurehead. In the Book of Songs (《诗经》), changed mood and elegance (变风变雅) had developed the ideas of blaming Heaven and scolding gods. On this background that Zichan made the practical transition in the topmost principle of social system from nature to man becoming true, which made a strong basis for the reconstruction of the social system. And the society now had a new understanding of fate. Pi Chen (裨谌), an official of Zheng state (郑国), took Zichan's principles in governing the Zheng state as a phenomenon demonstrating heaven's will, after he had viewed the social, economic, and political situations of Zheng very closely. $\mathrm{He}$ observed in 536 BCE:

The good men will replace the bad men. This is heaven's will. The power should not avoid Zichan. If a promotion follows the order without being more than one grade at a time, he should be in power. To elevate the good and virtuous is respected by the people. Heaven has cleared away the obstacles on the road; Bo You (伯有, once who governed Zheng state) has lost his soul and Zixi (子晳) will die soon. How can Zichan escape from the power? Heaven has made Zheng troubles for long, now it will let Zichan pacify these troubles and make our state peace and ease. If not, the state of Zheng will be destroyed. (Zuo, 2017: p. 352)

"The heaven's will" had been an estimation and understanding of the inevitable development law of objective things. In this background, Zichan put forward ideas about the heaven's will. After large fire calamity took place in Zheng, the people of Zheng begged Zichan to adopt Pi Zao (裨灶)'s words, sacrificing precious articles to gods to save the state from the ruin. Zichan refused and said in 524 BCE:

The way of heaven is far and far, but the way of man is near and here. The way of heaven is not related to the way of man, what is the reason you said that there is relation between the two ways? How could Pi Zao know the way of heaven? This man is too like to say. Though some words may come true, it is mere a chance. (Zuo, 2017: p. 446)

It seemed that the status of God, actually, had been transformed from dominating people to allowing popular aspirations in the Spring and Autumn Period. Then in the competition among various countries, the decisive action demanded by public attitudes had been growing, and people gradually realized the foundation of governance with the protection of the state. At the same time, the role of people in the capital was powerfully manipulated. The outcomes of infightings 
between nobles were often decided by the people of the capital, and the nobles made covenants with the people of the capital frequently. For example, "Zisi (子 驱, who administered the government of Zheng state) led the people of the capital to the ancestral temple, where they made a covenant" (578 BCE); "Duke Jian (郑简公) of Zheng made a covenant with the people of the capital outside the gate of Shizhiliang (师之梁)” (543 BCE). Also the people of Zheng State had the traits of advocating change, revolutionary behaviours and the value orientation of upholding the sword. ${ }^{3}$

Thus, it appears from this brief historical analysis that ultimately "the people", guided by wise administrators such as Zichan, had realistically appraised the claims of "the gods" for supremacy, in favor of a humane and rational doctrine of the government. In this ideological background, social governance was gradually liberated from the shackles of old religious traditions, and the social governance thoughts of "benefiting the country" and "salvation" had developed the ideological trend of paying attention to person. When You Ji (游吉), the man who came to power of Zheng after Zichan, asked him about the governmental affairs. Zichan said in 517 BCE:

To administer government is like to farm in the fields, and one must think how to start and how to end from morning till night. Besides he must do what he thought both morning and night. What he does could not go over what he had contemplated, as the boundaries of the fields. The going afar will invite errors. (Zuo, 2017: p. 323)

Akin to political or social governance perceived as farming, it was regarded as the being engaged in practical human affairs, and shall be started rationally and reflected on with the heart on how actions started and terminated. It was implemented according to the preplanned steps, as in farming, and never went beyond the goals of the planners. In that way, leaders made fewer mistakes. $\mathrm{Zi}$ chan's social governance ideas of attaching importance to people were based on the principle of actions "mainly benefiting the people" and "helping the people".

\subsection{Virtue-Governing of Zichan}

When Shi Gai (士包) governed the state of Jin (晋), the tribute levied by the allied states got heavier. The people of Zheng could not bear such heavy burden. Zichan entrusted Zixi to hand a letter to Shi Gai when Zixi went to the state of Jin in 549 BCE. The letter declares:

Good reputation is the carriage to load morality and integrity, and morality and integrity are the foundation of a state. The foundation has been well built, the state will not be harmed. Should you not wish to do it well? One who has morality and integrity will be joyful and joy within one's mind... To carry forward morality and integrity with your kind and honorable mind, your name spread everywhere. The people afar will come to you and those neighbors will be

${ }^{3}$ The formation and performance of traits about Zheng, the readers can refer to the paper: Yang, Xiuli (2008). Three treatises on peripateticism of Zheng's songs. The songs research series. (Vol. 15). 113-124. 
in ease and rest. Would you like hear "It is you who nourished us all" of "it is you who extorted all us to nourish yourself? The elephant is destructed by its own tusks. This is because the tusks are so valuable. (Zuo, 2017: p. 314)

According to these principles, good reputation, morality and integrity of the minister are the most important foundations of a state, which can enable people to live a happy and healthy life. China's traditional social order was based on "Paradigm politics". There is a direct and inevitable connection between the leader's moral cultivation and social order (Chang, 1993). As far as the Chinese social tradition is concerned, the disintegration of the ritual and music system basically lies in the moral problems of the governors themselves. From this point of view, for Zhou after the collapse, to rebuild a new social system must be built based on the model of politics. This is consistent with the popular sentiment, representing the general trend. "The conduct of government, therefore, depends upon the men. The right men are obtained by the governor's personal character. To put in order his personal character, the governor must use the moral law. To put in order the moral law, the governor must use the moral sense" (Ku, 1996).

It is, in Zichan's principles, true that "benefiting the people" and "helping the people" is the way that can make the state's roots stable. When King Ling of Chu (楚灵王) consulted Zichan about whether the state of Jin should allow the princes of other states to come over to $\mathrm{Chu}$, and how he could realize his wish in 538 BCE Zichan said: "It is not feasible for you to seek pleasure from the others. If what you do keeps agreement with the others, success will be ahead" (Zuo, 2017: pp. 386-387). So those in an attempt to impose their will cannot do anything that is inconsistent with the aspirations of the people of their states, against whom things cannot be done contrarily. This is the basic practice for the rule of "benefiting the people" and "helping the people". When Zikong (子孔) took over the Zheng government after the rebellion of Wei Zhi, he made again a covenant, and requested all officials to stand fast at their posts and obey the command. Of those who did not follow him, Zikong was about to put them to death. But Zichan requested Zikong to burn that covenant, and said in 563 BCE:

Do not offend the mass's rage. The power you want to abrogate cannot be fulfilled. This is a dangerous way to make the state peace by use the combining of the two difficulties. You had better burn the covenant in order to pacify their rage. You gain what you desire to gain and they are all in peace. Is this not possible? The power you want to arrogate cannot be fulfilled and the offending of the mass will surely produce turmoil. You must follow them! (Zuo, 2017: p. 272)

In other words, the affirmative social adjustment was to encourage the people who could obey certain social norms, in a positive way, so as to promote certain behaviors. As one of the basic practice criterion, it was marked by Zichan's "morality" to realize the social governance, which relied on public opinion and social psychology to achieve social "soft control" by tolerating social customs, morals, faith and beliefs. The thoughts occurred when the people of Zheng were 
pleased about Ziguo and Zi'er who led an army to invade the state of Cai (蔡) and captured Gongzi Xie (公子偹), war minister of Cai in 565 BCE. On this, Zichan published a political view:

A small state does not administer its state with morality, but uses its army to invade the other state. Is there greater disaster than this? (Zuo, 2017: p. 262)

These words published by Zichan were scolded as "babyish speech" by Ziguo, Zichan's father. But the development of this event showed the extraordinary political vision possessed by Zichan. Both Jin and Chu attacked Zheng because of this event for several years. Moreover, the political concept of "morality", which was the guiding principle of Zichan's social governance ideas, has laid the foundation for social governance ideas to come to maturity in a form which can be developed by later generations and remains applicable in modern times. Zichan may thus be regarded as one of the "founding fathers" of a modern, rational and humane philosophy of the role of the state and its social governance in the People's Republic of China, and even in the wider world.

During the process of carrying out social governance, Zichan pursued his ideas of "morality", relevant for all levels of society in the ordering of the state. The social division of Zheng state was not a function of differentiation based on job differentiation, but a form of interest based on the separatism of different social interests groups. Thereby the balance and conflicts of interest have become the key factors that affect social order. When Zichan began governing the state of Zheng, he wished Bai Shi (伯石) to finish the task for him and gave him a town as present in $543 \mathrm{BCE}$. When he responded to You Ji's queries, Zichan said:

It says in Zhengshu [the Record of Zheng]: "A stable state is built on the treating of the great clans well at first... The first step is to make the great clans peace and then to see their actions." (Zuo, 2017: p. 357)

Giving priority to the domestic, major renowned families became Zichan's most important method of social governance, for the reason that in the State of Zheng, the renowned families which were influential are often to a large degree determined factors in social development, such as politics, economy and society. The renowned families played an important role in making the state of Zheng stable and harmonious, so giving priority to the domestic major renowned families in the state would maintain the state in stable solidarity. Therefore, at the beginning of his power, Zichan gathered together the prestigious groups, and ended the internal contradictions of the ruling class through various compromises, an expedient measure taken to stabilize the domestic political situation. His father Ziguo had died in the civil strife, and from this he drew a lesson: "It is hard to realize dictatorship and dangerous to incur the anger among the masses". Forces of power rallied around him, which left him a dominant influence in easing domestic contradictions and stabilizing the situation at home and abroad. For the public in the home state, what Zichan adopted was the democratic social governance method of encouraging free speech. The famous related 
case declared that "Zichan does not abolish the countryside school". When the people gathered in the countryside school to discuss the gain and loss of government affairs, one official of the state of Zheng suggested that the countryside school should be abolished in 542 BCE. But Zichan refused and said:

The people went there in leisure for the driving away of their cares, at the same time they talked of our ministers' success and failure. We may promote what they approve of and correct what they dislike. They are actually our teachers! Why should we abolish them? I am told that they can use loyalty and goodness to wipe out resentment, but I was not told that they use force and power to guard against it. How could we stop it by force at a time? It is like to prevent flood. When a large river burst its banks, it would hurt many people who could not be saved. So we may release the water break out in a small mouth and let the water flow in slow. In this case we may know what the people argue and take their complaints as medicine to cure our wounds. (Zuo, 2017: p. 362)

The phenomenon of Individual awakening started from political elites, and trampled over the ritual principles that advocated association with those that were closely related and honored, and those who were honorable. Like the comments and opinions of an individual about an event or a phenomenon, the public opinion consists of evaluations both right and wrong of the events or phenomena. Because the social public opinion is a kind of public opinion, and reflects the will of the majority, it can guide, restrict and control the words and deeds of the minority. In terms of its internal mechanism, public opinion, as the evaluative opinion, will be environmentally stressful for the minority and the different opinions and actions of people. In order to alleviate this pressure, a small number of people would change or abandon their original words and deeds to maintain consistency with others. There was no doubt that they still had a positive influence on the times, believing that the public discussions and the useful advice to correct any current malpractice would avoid social disasters, in the same way that the land is saved from overflowing rivers. The official suggested to Zichan: "From now on I know that you are really capable of managing government, I am but nothing, If we do as you said, it will benefit the whole state of Zheng, not only for a few minsters" (Zuo, 2017: p. 362). Accordingly, Zichan was highly praised by Confucius in his Analects, saying that: "In this way, it makes no sense that Zichan is unmerciful and ruthless as people said".

Zichan modified rituals appropriately to achieve his social governance designs. Rituals were one part of custom, and were the foundation of the mores and habits that gradually formed, which were accepted by the populace in the long term, in following their patterns of common life. Zichan transformed them moderately in order to guide and restrict people's behaviors and also to control the society to a certain extent, which for example was embodied in the manner in which people who violated etiquette would always be mocked, and isolated by people surrounding them. Thus, Zichan broke the exclusive situation of society that courtesy predominated, and insisted that people should be treated and 
guided politely, in a non-violent manner. Zhao Yang (赵鞅), a minister of Jin, asked You Ji "What is Propriety?" in 517 BCE You, Ji replied to Zhao Yang with the words he had heard from Zichan:

Propriety is the law of the heaven, the root of earth, and the dependence of the people. The laws of heaven and earth should be followed by the people... They formulate political decrees and every kind of laws and regulations to comply with the different seasons. They make criminal punishment, and build jails to make the people stand in awe of the power that imitates thunder and lightning; They stipulate these mild and kind policies to follow the natural law of the breeding of all things. (Zuo, 2017: pp. 473-474)

Taking rituals as the order and the law of nature, the social order and regulation were established, namely "etiquette". According to this, it was arranged by neither gods and deities nor the people, but the order and law existing in nature, which had definitely subverted the traditional version of religious mysticism. So the rituals that Zichan adulated broke the boundaries, meaning that "Ceremony did not descend to the common people".

In 535 BCE, when Bo You's ghost had, apparently, appeared in Zheng, which made the people in the city frightened, Zichan appointed Liang Zhi (良止, son of Bo You) and other officials in various positions: "The ghost who has a place to return to will not become an evil one and make troubles" (Zuo, 2017: p. 406). "A man who just dies changes into po [soul], and its yangqi [life energy] is called hun [spirit]. When a man is alive with satisfaction of plenty, his soul and spirit are as strong as gods. If the common man and woman suffer unnatural deaths, their hun-and-po may attach themselves to the others' bodies and become the evil ghosts" (Zuo, 2017: p. 406). This showed that Zichan applied, with humane ingenuity, certain idea on ghosts and gods, and the social governance implications for political affairs with an impressive appearance. Zichan replied to the query from You ji in $535 \mathrm{BCE}$ :

This is to make the people of our state pleasant. Gongsun Duan and Bo You were no moral and just in their lifetime, but only the ghost of Bo You made troubles. If I merely made Liang Zhi in office, it shows the going against morality and justice. The making Gongsun Xie in office will cause the people of our state to be in convivial psychology. Without the people's support is without their trust; without their trust, they will not listen to us! (Zuo, 2017: pp. 405 406)

These words showed the subtlety of Zichan when meeting such things like his people being frightened by ghosts. In Xuncius words, it was expedient to go with what people felt or desired in order to accommodate political affairs. He did this for the purpose of pacifying the population rather than appeasing gods. From this, we can see the great wisdom emerging in the social governance thoughts of Zichan.

\subsection{Law-Governing of Zichan}

Zichan advocated "governing of virtue", and at the same time he did not ignore the role of law system. But he did not think law is the essential means of social 
management. It was argued that there were fatal defects in the thoughts controlling society merely with the "morality": rather the positive social governance was required. Negative social governance, on its own, would punish people who violated social norms by means of certain sanctions so as to prohibit certain behaviors. It seemed more important for Zichan to govern in a positive manner and to balance the use of negative and positive sanctions.

As the paper had recounted the distinct characteristic and main trend of the social development during/in the Spring and Autumn period in the part of "Introduction". Zichan had been worried about the unruly aristocracy in his state. In $543 \mathrm{BCE}$, when Zichan declined to be appointed as the chancellor of Zheng State by Zipi (子皮), he analyzed the domestic situation at that time as "our state is small and pressed by the big states, and the ducal clan is so great and powerful that many members are favored. The incessant fights between them and the corruption of the governing class led to the upheaval of the society. It is difficult for me to govern well" (Zuo, 2017: p. 356), which had hit ade the point precisely. For example, after Zisi shifted boundaries of farmlands, which was made up of the four families of Si (司), Du (堵), Hou (侯) and Zishi (子师)一they had lost their estates. In this case Wei Zhi (尉止) united the former four families to gather those who felt discontented and depended on the prince's family (the princes killed by Zisi) to create a rebellion. They killed Zisi, Ziguo (子国, the minister of the army) and Zier (子耳, the minister of public works), and also forced Count Zheng into the North palace in 563 BCE. There were also threats to Zheng from the major powers in such states as Jin, Chu, Qin (秦). This caused a crisis of national subjugation at every turn. ${ }^{4}$

In this context, Zichan applied the social norms and the corresponding means and methods to guide and restrict this aggressive social behaviour and negative values, regulating all kinds of social relations, for the sake of achieving good social governance.

Two years later, the people of Zheng engraved the criminal law on a bronze tripod. This triggered the attention of Shuxiang (叔向), who was also a famous statesman in Jin. He sent a messenger with a letter to Zichan, and questioned Zichan as to why he passed these laws in 536 BCE. Zichan wrote back, saying:

According to your words, I am in certainly of no ability. I could not consider the future generations. What I think is to save today's Zheng. Though I cannot follow your order, I will remember what you teach me. (Zuo, 2017: p. 399)

As a staunch reformer full of ideas of benefiting the people, Zichan had always been courageous in facing others' criticism and accusations about the means and methods of his social governance. When Zichan formulated a system of village tax in 538 BCE, he told to Zikuan(子宽), an official of Zheng (who told Zichan that all of the people reproached him):

${ }^{4}$ Yang, Xiuli. (2013). The Obscene Style of "The Odes of Zheng" and Its Geo-strategic Relationship. Journal of Henan University of Science and Technology (Social Science Edition). (06), 13-16. This article also had been reprinted in its entirety by: Classical and modern Chinese literature. Information center for social sciences, RUC. 
As long as what I do benefits our country, I don't mind if life or death is for me. I am told that he who does goodness in changeless can be successful at the end. The people cannot be let to walk their own way, and laws cannot be changed. (Zuo, 2017: p. 390)

These words illustrated the social governance concepts of Zichan, which involve the desire to create a stable, orderly and developing social order, and the desire of realizing the administrative target of "benefiting the country" and "salvation". When he was ill in $522 \mathrm{BCE}$, he said to You Ji:

After my death you should hold power. Only he who is virtuous makes the people submissive by the use of clemency... Fire is fierce and violent which the people fear, so few die from the fire. Water is weak, which the people think lightly of and like to play with, so many die from it. It is much difficult to practice mild government. (Zuo, 2017: p. 458)

The ruling thoughts of "a proper mixture of severity and gentleness" and "temper justice with mercy" can be said to be the summary of political wisdom in Zichan's life. After Zichan's death, You Ji kept controlling the society merely with "morality". This led the state of Zheng to a situation in which robbers appeared and gathered among the reeds. So You Ji had to lead his troops to attack the robbers hiding among the reeds of the marshes until all robbers were killed. In this case the robbers were weakened and disappeared in Zheng state. In the patriarchal system society, propriety and law were two important norms to adjust people's behavior, and law and ceremony were mixed together. Law was used as a complement to propriety, which was the so-called "noble morality and cautious punishment". While law was the "governmental parasite on etiquette", it was not separated from the propriety of noble morality. Until the Spring and Autumn Period in which Zichan lived, the case that propriety and law were mixed together, and rituals embody law had yet not fundamentally changed. Even Zichan who cast the penal code and separated the law from the traditional rituals, still used to treat the legal penalty as one part of the rule which was embodied in the traditional rituals: "They make criminal punishment, and build jails to make people stand in awe of the powers that imitate thunder and lightning", and as a key component of the highest codes of the conduct of rituals, which was reflected in Zachin's "social governance thoughts and practice". Zixi (子晳) of Zheng planned to raise a revolt against You Ji and You's clan, and take You Ji's position in the state in 540 BCE. Due to the effect of an old wound, Zixi delayed his action. Si's family of Zixi's clan and other officials all wished to kill Zixi. Zichan sent an official to Zixi and enumerated his offenses, in a statement which said:

At Bo You's revolt, we were preoccupied with the service of the big state, and we did not punish you. You harbor a rebellion within your heart... You attacked Bo You as you pleased. This is the first crime of yours. You quarreled with your younger brother over his wife. This is the second crime of yours. At the meeting of Xunsui you showed the airs of a sovereign. This is the third of your crimes. We have the three capital crimes against you, how can we still put up with you? 
If you delay to kill yourself, the execution will surely fall down to you! (Zuo, 2017: p. 378)

Zixi hanged himself several days later, and his corpse was exposed on the main street. A piece of wood on which his crimes were recorded was put on the corpse. Zichan's penalty that focused on fierce politics reflected the times, and it frequently occurred in some remarks of hexagram lines of the Book of Changes (《易经》). And Confucius who had been respecting “rituals" was conscious of the role of the law and put forward the concepts of "morality given priority over penalty". He commended: "The political way, together with punishment, people's freedom and shamelessness... together with propriety, sense." For the sake of better pushing the social governance thoughts in parallel with his own law and etiquette, to get more credence and realize the main ruling goal was to protect people and the state, Zichan developed expedient ways of government and rational reforms in the course of social governance. It may be said that Zichan's pioneering philosophy and practice of governance laid a pathway for subsequent Chinese philosophers and pioneers of political thought, including Confucius.

\subsection{Evaluation of Zichan's Social Governance}

Zichan denied the extramundane position of fatality and internal human nature in the social system. His "Combination of Law-governing and Virtue-governing" thought had historical significance. It provided ideas and value for ancient Chinese social governance and cultural cultivation. In the Spring and Autumn period slaveholders were transformed into a feudal landlord class, and it was the realistic tendency of Zichan to support this transition with a logical and humane philosophical system, and with new values (the implicit thesis-antithesis system of value change) arose a completely new ideological system. This ideology has a strong realistic style, responds to the calls for rebuilding the value of faith, and answers to build a new social order of his age. Through his pragmatic social governance, the State of Zheng was well governed and Zichan also achieved great success with an enduring legacy, as it was told in The Records of the Grand Historian (《史记》) authored by Ssu-ma Ch’ien (司马迁):

The state of Zheng was in the situation of political turmoil, with social tensions between the officials and the people. After Zichan took office a year later, the prodigals were no longer rebelliously deviant, the elderly did not have to do hard work, children did not need to farm the fields. Two years later, fair buying and selling occurred in the market. Three years later, doors were unbolted at night, and lost articles were always returned in Zheng state. Four years later, the farmers did not need to take their farm implements home after their work. Five years later, men did not need military service, and the funerals were conscientiously implemented with the relevant funeral etiquette. When Zichan died after he had administered the Zheng state for twenty-six years, the people in the Zheng state cried sadly, and said that Zichan had left them dead, they did not know now, on whom would depend. 
At the same time, the social governance implemented by Zichan had not isolated the people from the traditional rituals of Zhou; rather, these had been gradually corrected. However, Zichan's thoughts on etiquette and law encouraged the freedom and development of the people in face of the state, which was reflected in the "realistic popular and historical development" in his time. Zichan's thoughts affected deeply many philosophers' ideas on the governance of the states. Confucianism is responsible for creating the world's first meritocracy. Confucius, praised Zichan as "So kind and loving one, he has the way accepted from the ancient sage!" (Zuo, 2017: p. 459) who once remarked of Zichan's thought "The government that is mild makes the people idle; when they are idle, severity is used to temper severity. Use clemency and severity to correct each other, and government affairs become harmonious" (Zuo, 2017: p. 459). It is clear from Zichan's thought that he anticipated Confucianism in taking morality seriously, taking the law and the punishment as important means of adjusting social relations and maintaining social order.

However, we can also clearly recognize that, the law reflects the interpersonal power relation, and the propriety embodies the cooperative one. Zichan was a man who lived two thousand years ago. Zichan's "Combination of Law-governing and Virtue-governing" thoughts may have some limitations in today's world. As Zichan was living in a patrician family, and took a prominent position, so it was impossible for him to break with the tradition of slaveholders. For example, Zichan engraved the criminal law a bronze tripod, which had restricted the privileges of the aristocracy, and a lot of 'slavery thought' remained, so the content and nature of the criminal law reform was incomplete.

Lastly, in the social governance of Law-governing and Virtue-governing about Zichan, more belonged to the political practices, and neither the theoretical system nor the independent school and ideological system were formed. So Zichan was simply a forerunner of different philosophers and authors in the time of Warring States.

\section{Conclusion}

The transformation of China's contemporary society has not only brought rare strategic opportunities, but also becomes increasingly complicated, and sometimes offers conflicting modes of thought. The whole nation is faced with challenges on many aspects of ideas, ways of thinking, lifestyles and behavioral patterns, in a dramatic manner as the value system and benefits structure triggered by reform are opening up market economies. The deepening reforms and the strengthening of market regulation have highlighted the increasingly prominent contradictions and deep-seated problems in social life. The mode of Zichan's "virtue-governing" and "law-governing", cannot be simply copied, but should adapt to the new characteristics of the times in ingenious ways, to insure the society may absorb the beneficial ingredients of social change. There is also an urgent need to set up a theory of social governance with Chinese characteristics on 
the basis of conscientiously studying and learning from the main points of the Western governance theories.

Methodologically, the effective social governance implemented in the State of Zheng, guided by thoughts and practice of Zichan, has enriched the theoretical resources for contemporary China. Zichan's ideas, his wise and ingenious pragmatism, his humanity and commonsense, his incorporation of all of the society's institutions into a harmonious and co-operating whole have much to offer modern political philosophers, not only in China, but also in Western thought.

Combination of the Law-governing and Virtue-governing of Zichan was based on the authoritarian society, so the effective social governance implemented may not express the content of equal rights. Only with "severe law" was the governing of social policy, law-governing (leading to the auxiliary form of virtue-governing), and the terms of legal content and form focusing on punishment, successful. In Ancient Greece and Rome, the basic logic of social governance was markedly different: the western classical theory of social governance was based on a democratic society, and equal civil rights for the pursuit of "right law" as the core. Plato (427 327 BCE) once said: "For that state in which the law is subject and has no authority, I perceive to be on the highway to ruin; but I see that the state in which the law is above the governors, and the governors are the inferiors of the law, has salvation, and every blessing which the Gods can confer" (Plato, $360 \mathrm{BCE}$ ). To realize the refinement of the legal system and the strictness of the system was the characteristic of Law-governing of western thought. Of course, there are many different ways in which these principles can be understood. For example, in the West there is a growing interest in the Analects of Confucius (Van Norden et al., 2002), and it would be interesting to explore how Zichan's pragmatic humanism fits in with this debate. There may be strong parallels between the balancing of metaphysics, social pragmatism of Aristotle (the father of much Western ethical writing), and the approaches of Zichan. Yu (2007) has given us a valuable comparison of the ethical approaches of Confucius and Aristotle, and it would be most interesting to have further work on such comparisons, introducing the writings of Zichan into the methodological matrix of comparison.

\section{References}

Chang, J. C. (1993). Paradigm Politics and Its Cultural Foundation in the Western Zhou Dynasty Symposium on Western Zhou History (p. 706). Xi'an: Shaanxi People's Education Press.

Ku, H. M. (1996). The Universal Order or Conduct of Life. Ku Hungming's Corpus (p. 547). Haikou: Hainan Press.

Zuo, Q. M. (2017). Zuo Zhuan. Translated by Luo Zhiye. Nanjing: Southeast University Press.

The Commission on Global Governance (1995). Our Global Neighbourhood (p. 4). Oxford: Oxford University Press.

Plato (360 BCE) Laws. Translated by Benjamin Jowett. 
http://classics.mit.edu/Plato/laws.html

Van Norden, B. W. (2002). Confucius and the Analects: New Essays. Oxford: Oxford University Press.

Yu, J. Y. (2007). The Ethics of Confucius and Aristotle: Mirrors of Virtue. London: Routledge.

Submit or recommend next manuscript to SCIRP and we will provide best service for you:

Accepting pre-submission inquiries through Email, Facebook, LinkedIn, Twitter, etc. A wide selection of journals (inclusive of 9 subjects, more than 200 journals) Providing 24-hour high-quality service User-friendly online submission system Fair and swift peer-review system Efficient typesetting and proofreading procedure Display of the result of downloads and visits, as well as the number of cited articles Maximum dissemination of your research work

Submit your manuscript at: http://papersubmission.scirp.org/ Or contact aasoci@scirp.org 